\begin{tabular}{|c|c|c|c|c|c|}
\hline ISRA (India) & $=3.117$ & SIS (USA) & $=0.912$ & ICV (Poland) & $=6.630$ \\
\hline ISI (Dubai, U) & $=0.829$ & РИНЦ (Russia) & $=0.156$ & PIF (India) & $=1.940$ \\
\hline GIF (Australia) & $=0.564$ & ESJI (KZ) & $=8.716$ & IBI (India) & $=4.260$ \\
\hline JIF & $=1.500$ & SJIF (Morocco) & )$=5.667$ & OAJI (USA) & $=0.350$ \\
\hline
\end{tabular}

\section{SOI: $\underline{1.1 / \mathrm{TAS}}$ DOI: $\underline{10.15863 / \mathrm{TAS}}$ International Scientific Journal Theoretical \& Applied Science}

\author{
p-ISSN: 2308-4944 (print) e-ISSN: 2409-0085 (online) \\ Year: 2019 Issue: $04 \quad$ Volume: 72
}

Published: 24.04.2019 http://T-Science.org
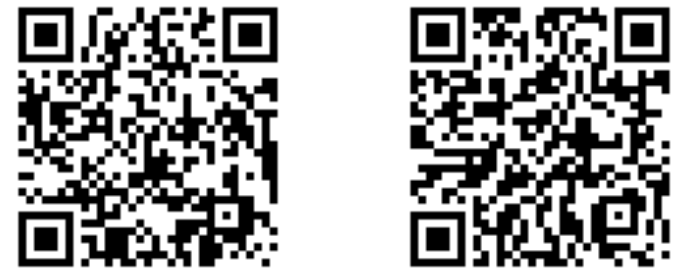

S.A. Abdukhamidov Independent researcher, Samarkand Institute of Economics and Service, Samarkand savar2102@mail.ru

\title{
DISTINCTIVE FEATURES OF REGIONAL TOURISM DEVELOPMENT
}

Abstract: The article focuses on the peculiarities of regional tourism development, highlighting socio-economic aspects of regional and regional tourism concepts. It also deals with regional tourism with its economy, society and nature, the direct impact of tourism on the development of the region, and the establishment and sale of products in regional tourism.

Key words: tourism, region, gross domestic product, service, tourist route, regional tourism, service, transport, export, tourist resources.

Language: English

Citation: Abdukhamidov, S. A. (2019). Distinctive features of regional tourism development. ISJ Theoretical \& Applied Science, 04 (72), 337-341.

Soi: http://s-o-i.org/1.1/TAS-04-72-41 Doi: crossef https://dx.doi.org/10.15863/TAS.2019.04.72.41

\section{Introduction}

As an independent network of modern tourism economics, it occupies a leading place among the world's most profitable industries. It is well known that the world practice is now regarded as the oil extraction and processing industry and the postautomotive sector in terms of profitability and sustainable growth in the tourism industry.

According to the World Tourism Organization (UNWTO), tourism is the world's fourth largest exporter of goods and services, and third in revenue. Its share in the world GDP is $10 \%$. These figures show the direct economic effectiveness of tourism industry

The tourism industry has grown rapidly in the last 30 years. During this time, the number of international tourists increased 3.8 times, and the profit from this industry grew 25 times. Currently, tourism accounts for 10 per cent of the world's gross domestic product, 7 per cent of international capital, 16 per cent of jobs, and 12 per cent of world consumption. Today, tourism is a very powerful branch of the global economy, with a large number of staff, major equity and major capital investments involved. Tourism is a large-scale business, with huge money and global policy [1].

As can be seen from the information above, tourism is now an important component of the economy and has a practical impact on all sectors of the national economy. At the same time, its socioeconomic significance is shaped as a powerful network that enhances the quality and quality of dignified people. Thus, one of the most pressing issues of today is the development of tourism at a steady pace, raising it to new levels, forming modern tourist infrastructure, increasing the range of tourist services, improving service quality, maximizing tourist potential of the regions.

\section{Main part}

Tourism industry is one of the sectors of tourism in the national economy of the Republic of Uzbekistan, which is rapidly developing and providing currency flow to the economy of the country.

After the independence of our country, the development of this sphere has begun at the state policy level, and nowadays the legal framework for the development of tourism is being created and great work is underway.

Uzbekistan has all the opportunities for the rich tourist potential and the development of tourism, and the Presidential decrees and resolutions have been adopted and implemented for the development of tourism in our country. Decree of the President of the Republic of Uzbekistan Sh.M.Mirziyoev on February 3, 2018 "On additional organizational measures to create favorable conditions for the development of tourism potential of the Republic of Uzbekistan", 


\begin{tabular}{|c|c|c|c|c|c|c|}
\hline \multirow{4}{*}{ Impact Factor: } & ISRA (India) & $=3.117$ & SIS (USA) & $=0.912$ & ICV (Poland) & $=6.630$ \\
\hline & ISI (Dubai, UAE & $=0.829$ & РИНЦ (Russia & $=\mathbf{0 . 1 5 6}$ & PIF (India) & $=1.940$ \\
\hline & GIF (Australia) & $=0.564$ & ESJI (KZ) & $=8.716$ & IBI (India) & $=4.260$ \\
\hline & JIF & $=1.500$ & SJIF (Morocco & $=5.667$ & OAJI (USA) & $=0.350$ \\
\hline
\end{tabular}

dated February 6, 2018 " On Measures for Further Improvement of the State Committee for Tourism Development of the Republic of Uzbekistan "No. PP3509" On additional organizational measures to create conditions", PQ-3510, February 7, 2018 "On measures to accelerate the development of domestic tourism", PF-5611 "On additional measures to accelerate the development of tourism in the Republic of Uzbekistan" of January 5, 2019 could be included in this decree.

In our country, the development of this sphere is at the level of state policy and a number of work is underway. In particular, as a result of measures to stimulate small businesses and private entrepreneurship, the number of tour businesses has been increasing, and tourism services in the services sector have been interpreted as a modern service, with a focus on public policy.

Tourism creates opportunities for people to enjoy and relax. So tourism is the most important thing to satisfy the pleasure of the person for pleasure and pleasure. But it is noteworthy that tourism is not a product of the most vital need for tourism, but at a certain level of human income and at the same time as it may be at leisure and time.

Tourism is characterized by temporary movement from one region (district, city, country) to another, unless it relates to the change in the living and workplace. Tourism is a process related to holidays, treatment, cultural, scientific and business meetings. Realization of services in the sphere of tourism is carried out as a commodity.

The tourism potential of the local population and foreign citizens on the history, historical architecture of the country, the local population's traditions, traditions and ceremonies, along with their relaxation and treatment, has a direct positive impact on the country's economy.

Tourism is a leading industry in the country, and it promotes the development of some forms of economic activity that is collaborating with tourism. The purpose of tourism in the educational aspect is that people gain knowledge and experience as a result of traveling, and they will endure hardships, overcome difficulties, overcome and appreciate the country, respect the world outlook and traditions [2].

In the region the production of tourist goods and services is carried out jointly with other sectors and branches, ie national tourist products are formed and realized. As a result, the share of tourism in the GDP and the country's balance of payments is constantly increasing.

Tourism serves as a major catalyst for the economic growth of the region and countries, and positively affects the economy of the countries.

In addition to tourism, it also carries out a number of social functions, such as the restoration of labor skills of the population, the establishment of large-scale production, cultural awareness and the aesthetic development of society.

\section{Discussions and results}

In addition to tourism, tourism also carries out a number of social functions, such as the restoration of the working capacity of the population, the establishment of production, cultural awareness and aesthetic development of society

Tourism has a direct positive impact on the economies of the region and countries and serves as the main catalyst for their economic growth (Figure 1).

When a tourist intends to go somewhere, he compares the other types of services available there and chooses what he likes. Ordered and purchased by tourists includes the services of the tourist area, where the tourist services are offered. Tourist region is different from other places by attracting tourists with its attractiveness.

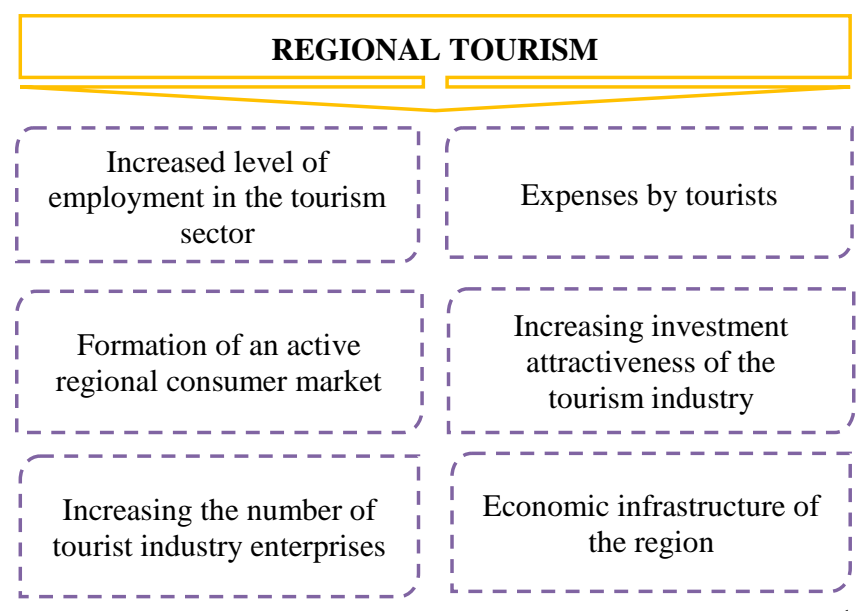

Fig. 1: Direct Impact of Tourism on Regional Development ${ }^{1}$ 


\begin{tabular}{|c|c|c|c|c|c|c|}
\hline \multirow{4}{*}{ Impact Factor: } & ISRA (India) & $=3.117$ & SIS (USA) & $=0.912$ & ICV (Poland) & $=6.630$ \\
\hline & ISI (Dubai, UAE & $=0.829$ & РИНЦ (Russia & $=0.156$ & PIF (India) & $=1.940$ \\
\hline & GIF (Australia) & $=0.564$ & ESJI (KZ) & $=8.716$ & IBI (India) & $=4.260$ \\
\hline & JIF & $=1.500$ & SJIF (Morocco & $=\mathbf{5 . 6 6 7}$ & OAJI (USA) & $=0.350$ \\
\hline
\end{tabular}

The BTT describes the tourist region as an area where special resources and services are available for holidays and recreation. From this perspective, we can conclude that regional tourism is a place where resources for the future of tourists and the infrastructure to facilitate their arrival are considered.

Touristic region can be considered in view of tourists' demands. Tourists can visit this area again once they get a touristic motivation. In practice, the tourism industry reflects the following parameters: accommodation, location and location of resources, attractive view of the area and facilities and excursions.

The concept of regional tourism is related to the following aspects: firstly, the distribution of recreational resources, the recreational needs of the local population, and the level of satisfaction in a particular area, as well as the ability to attract foreign tourists. Secondly, the level of recreational development in the region indicates a region that sets socioeconomic conditions that can encourage or limit the role of the region and tourism in the domestic and world tourism markets.

The first approach basically reflects the idea of potential tourism development, the second is the result of tourism activity in the region, which allows it to be included in a separate segment of the tourist market. As a result, the tourist area is evaluated from the point of view of holiday organizations and local or leisure travelers. ${ }^{2}$

As far as the concept of the region and the "regional tourism" is concerned, the meaning of this term is explained by scholars in various sociological and economic geography, such as regional economics, the theory of public administration, and politology. In most publications, the word region is primarily referred to a region with the same natural conditions, specific economic, demographic, historical conditions, and industrial and social institutions specialized in certain types of industry.

In general, according to the study of scientific literature, the term "region" can be used in various meanings, depending on what dimension of life it describes.

Region (from lat. Regio - region), a vast area corresponding to several regions (districts) or several countries, united by economic, geographical, cultural, historical or other features and conditions of life. The complex socio-economic and political system with fuzzy system-forming features, in structural terms, basically coincides with the national-state structure of the world and the national-territorial division of the country. For the region it is peculiar to the socioterritorial community of people and countries that has its own interests, including in the field of regional security ${ }^{3}$.

Scientists of our country have described the concept of "region" on different approaches and gave their scientific conclusions. For example, Professor I. Tukhliev, in his scientific work, described the region as "a geographically divisive part of a large region that is formed when one or more criteria apply to a particular region" [3].

O. Akhmedov and N.Bakhriddinov are a regional geographical, historical, national and cultural unity, religious-etiquette, socio-economic development, administrative system at various stages of development, as well as socio-economic and environmental problems. the territorial unit [4], which necessitates joint co-operation.

When commenting on the concept of the region, it is not expedient to justify its economic aspects - the specialization of farming, the location of the labor force and the development of integration processes. In this regard, it is important not to ignore the interest of the population as a social community. Because of the social and economic interest of the region, the growth of employment and living standards for the population, social and economic protection, education, culture, promotes the development of ethnic identity.

It is noteworthy that today, the promotion of regional tourism plays an important role in our country. At the same time, the region is one of the pressing issues of studying regional tourism concepts, studying regional potential of our country, analyzing trends in tourism development in the regions(Adams, 2004; Manhas, Kour, \& Bhagata, 2014; Scheyvens, 2002).

L.V.Kovineva believes that tourism is closely linked to many sectors of the regional economy and it is expedient to consider "regional tourism" in three dimensions - geographical, socio-economic and environmental aspects. According to the above, the tourist region can be defined as a separate territorial unit united by nature, which has its own physical, ecological, economic, ethnic, historical, political, administrative and legal features [5].

EA Zaliznyak Regional tourism is a region where tourism, infrastructure, ecological and personal safety, and many other elements, which are interconnected, serve as a necessary condition for the satisfaction of tourist needs. .) is a highly complex, organized system [7]. 


\begin{tabular}{|c|c|c|c|c|c|c|}
\hline \multirow{4}{*}{ Impact Factor: } & ISRA (India) & $=3.117$ & SIS (USA) & $=0.912$ & ICV (Poland) & $=6.630$ \\
\hline & ISI (Dubai, UAE & $=0.829$ & РИНЦ (Russia) & $=0.156$ & PIF (India) & $=1.940$ \\
\hline & GIF (Australia) & $=0.564$ & ESJI (KZ) & $=8.716$ & IBI (India) & $=4.260$ \\
\hline & JIF & $=1.500$ & SJIF (Morocco) & $=5.667$ & OAJI (USA) & $=0.350$ \\
\hline
\end{tabular}

The territory offering a set of services does not always have an explicit set of limits. It can be a tourist center with all the necessary material and technical basis for organizing a part of the region and recreation. This area can cover any region, country, or even a group of tourists(Fauziah \& Aryanto, 2012; Luong, 2002; Studies \& 2009, n.d.).

The BTT defines the tourist area as a region with a great network of special facilities and services needed to organize the recreational process. Depending on this feature, the touristic region must be considered as independent and must have all the conveniences necessary for tourists to stay there. That is, tourist destination is determined by tourist attractions and services selected by tourists and tourists.

The Encyclopædia Britannica describes regional tourism as "tourist-oriented, to the continent of the region of the sovereignty of the country, or to the territory of the territory of the United States of America, the tourism industry and the tourism industry."

Formation and sales of tourist goods in regional tourism are carried out within the enterprises of this region. Among such undertakings the following can be included (Figure 2).

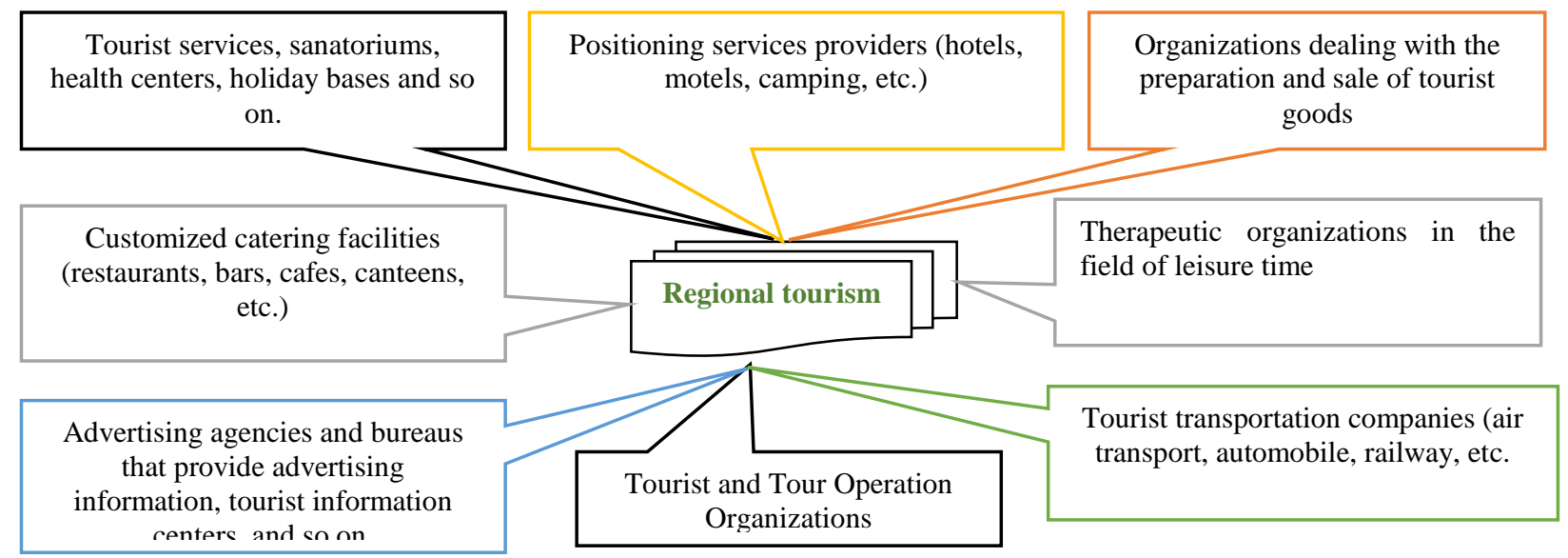

Fig. 2. Enterprises and organizations for the production and sale of products in regional tourism

The main result of the tourism development in the region is the attraction of tourists to their leisure time. During touristic trips, tourists spend more money than their normal lifestyle, so the tourism industry will provide the local market with additional currencies and improve the regional balance of payments.

\section{Conclusion}

In summary, we can say that the region is a region bordered by a group of countries or provinces.
Regional tourism is a regional tourism that provides touristic services, which is of particular interest to tourists, with the opportunity to meet the needs of tourists using natural, climatic, cultural and historical resources, entertaining or other complexes.

The region does not need to have clear borders, as the region can cover any region, even a group of countries. The Tourist Zone is the place where sightseeing and tourist attractions and services are adapted by tourists or tourists.

\section{References:}

1. Boltabayev, M. R., Tuxliev, I., Safarov, B. S., \& Abduxamidov, S. A. (2018). Tourism: theory and practice. Textbook. Tashkent: Science and Technology.
2. Holikulov, A. (2010). The possibilities of improving the quality and efficiency of hotel services (in the case of Samarkand hotels") is a dissertation for the degree of candidate of economics. Q. 


\begin{tabular}{|c|c|c|c|c|c|c|}
\hline \multirow{4}{*}{ Impact Factor: } & ISRA (India) & $=3.117$ & SIS (USA) & $=0.912$ & ICV (Poland) & $=6.630$ \\
\hline & ISI (Dubai, UAE & $=0.829$ & РИНЦ (Russia & $=0.156$ & PIF (India) & $=1.940$ \\
\hline & GIF (Australia) & $=0.564$ & ESJI (KZ) & $=8.716$ & IBI (India) & $=4.260$ \\
\hline & JIF & $=1.500$ & SJIF (Morocco & $=5.667$ & OAJI (USA) & $=0.350$ \\
\hline
\end{tabular}

3. (2004). Strategy macroregionov Rossii: Metodologiche-skie podxody, priorityit $i$ puti realizatsiya. pod red. G.Granberga (Eds.). (p.479). Moscow: Nauka.

4. Tukhliev, I., \& Pulatov, M. (2019). Explanatory phrase about modern terms of tourism industry. S..

5. Akhmedov, O., \& Bahriddinov, N. (2007). Actual problems of modern geography. (p.10). A..

6. Kovyneva, L. V. (2005). Regional tourism: monograph. (p.12). Khabarovsk: DVGUPS Publishing House.

7. Zaliznyak, E. A. (2011). Regional tourism: the main features and conditions of development. Bulletin of Volgograd State University. Series 3: Economy. Ecology, № 2 .

8. Adams, K. M. (2004). The genesis of touristic imagery: Politics and poetics in the creation of a remote Indonesian island destination. Tourist Studies, 4(2), 115-135. https://doi.org/10.1177/1468797604054378

9. Fauziah, S., \& Aryanto, R. (2012). Journal the winners: economics, business, management, and information system journal. The Winners (Vol. 13). Retrieved from https://www.neliti.com/id/publications/27053/c onsumer-preferences-toward-marine-tourismarea

10. Luong, P. (2002). Institutional change and political continuity in Post-Soviet Central Asia: power, perceptions, and pacts.

11. Manhas, P. S., Kour, P., \& Bhagata, A. (2014). Silk Route in the Light of Circuit Tourism: An Avenue of Tourism Internationalization. Procedia - Social and Behavioral Sciences, 144, 143-150. https://doi.org/10.1016/j.sbspro.2014.07.283

12. Scheyvens, R. (2002). Tourism for Development: Empowering Communities. Themes in Tourism Series (Vol. 27). https://doi.org/10.1016/j.tourman.2005.07.013

13. (2009). Studies, M. D.-J. of C. A., undefined. (n.d.). HIGHER EDUCATION IN UZBEKISTAN. Search.Ebscohost.Com. Retrieved from http://search.ebscohost.com 